\title{
Chondriokinesis during microsporogenesis in plants
}

\author{
Dorota Tchórzewska ${ }^{1}$
}

Received: 14 January 2017/ Accepted: 29 April 2017/Published online: 8 May 2017

(C) The Author(s) 2017. This article is an open access publication

\begin{abstract}
Main conclusion Chondriokinesis represents a highly orchestrated process of organelle rearrangement in all dividing plant and animal cells, ensuring a proper course of karyokinesis and cytokinesis. This process plays a key role in male gametophyte formation.
\end{abstract}

Chondriokinesis is a regular rearrangement of cell organelles, assuring their regular inheritance, during both mitotic and meiotic divisions in plant and animal cells. The universal occurrence of the process implies its high conservatism and its probable origin at an early stage of plant evolution. The role of chondriokinesis is not only limited to segregation of cell organelles into daughter cells, but also prevention of fusion of karyokinetic spindles and delineation of the cell division plane. Thus, chondriokinesis plays an indispensable role in mitosis and meiosis as one of the various factors in harmonised cell division, being a key process in the formation of viable cells. Therefore, disturbances in this process often result in development of abnormal daughter cells. This has far-reaching consequences for the meiotic division, as emergence of abnormal generative cells impedes sexual reproduction in plants. This review is focused on microsporogenesis, because various plants exhibit a problem with sexual reproduction caused by male sterility. In this paper for the first time in almost 100 years, it is presented a compilation of data on chondriokinesis proceeding during microsporogenesis in plants, and providing view of the role, mechanism, and

Dorota Tchórzewska

dorota.tchorzewska@poczta.umcs.lublin.pl

1 Department of Plant Anatomy and Cytology, Maria CurieSkłodowska University, Akademicka 19 Street, 20-033 Lublin, Poland classification of this process in male gametophyte formation.

Keywords Meiosis - Microsporogenesis - Cell organelles · Chondriokinesis

\section{Introduction}

In plants, a haploid generation of the male generative line, which is directly involved in sexual reproduction, emerges through a process called microsporogenesis in spermatophytes-gymnosperms and angiosperms. A crucial role in this complex multi-step process is played by meiotic division comprising karyokinesis (nuclear division) and cytokinesis (cytoplasm division). Karyokinesis consists of two stages; the first stage involves the reduction division of chromosomes and is characterised by recombination leading to exchange of genetic material between homologous chromosomes. This extremely important process results in increased genotypic diversity and adaptation to environmental fluctuations (Harrison et al. 2010; Wijnker and Schnitter 2013). The second stage of karyokinesis has a conservative, mitotic nature, finally producing four independent nuclei. The second step, cytokinesis, in a majority of monocotyledonous angiosperms, and some gymnosperms exhibits successive cytokinesis taking place during meiosis (Sheffield and Bell 1987; Brown and Lemmon 1988b; Furness and Rudall 1999). In this process, a callose wall is formed between two nuclei in the first karyokinesis stage, and the second stage proceeds within the dyad. In Bryophyta, Pteridophyta, and dicotyledonous angiosperms, simultaneous cytokinesis predominates-the cell wall is formed already at the end of meiosis after both stages of karyokinesis (Davis 1966; Kapil and Bhatnagar 
1991; Shimamura et al. 2003; Brown et al. 2010; Brown and Lemmon 2013). Besides these two main types, intermediate cytokinesis types are distinguished (Murty 1964; Bhandari 1984; Blackmore and Crane 1998). Finally, four haploid cells with half the chromosome number of the mother cell are formed through meiosis.

As early as at the turn of the 19th and 20th centuries, it was observed that karyokinesis and cytokinesis were accompanied by characteristic rearrangements of cell organelles, a process called chondriokinesis, during cell division (Fullmer 1899). It was found later that cell organelles (chondrion) did not migrate in a random way during the cell division stage, but exhibited a specific pattern of cellular distribution (Marquette 1907, 1908; Michaelis 1955). In subsequent studies, the authors demonstrated, using a mathematical approach, that organelle partitioning is not precisely uniform, but is much more nearly uniform (Birky 1983; Birky and Skavaril 1984). Recent investigations have shown that movement and distribution of organelles proceed in a highly organised manner with the involvement of the cytoskeleton, which ensures high precision of the distribution (Sheahan et al. 2004; Tchórzewska et al. 2008; Tchórzewska and Bednara 2011). Already in 1924, Guilliermond was the first to discover that "changes in the chondriosome", i.e. rearrangements of cell organelles, were as important as chromosome segregation and later, based on several observations, the first classification of chondriokinesis was systematised in 1938 (Bakkowski 1938). The proposed classification comprised four main types of chondriokinesis: neutral, capsular, polar, and equatorial. Additionally, intermediate types, e.g. capsular-polar chondriokinesis, and more complex types, e.g. neutral chondriokinesis equatorial during telophase have also been included. The key criterion for classification of the chondriokinesis types was the arrangement of cell organelles during two meiosis phases: metaphase I and telophase I. The first comprehensive description of numerous variants of chondriokinesis described by Bąkowski indicates a large variety of rearrangements of cell organelles during cell division, characterising different plant species and in some animals.

Chondriokinesis later on was recognized as a very important process, as it involves migration of semi-autonomous organelles, such as plastids and mitochondria. These organelles with their own DNA are involved in the so-called cytoplasmic inheritance; therefore, their precise distribution to daughter cells determines formation of identical, viable microspores (Chase 2006). Furthermore, disturbances in the distribution of these organelles often cause cytoplasmic male sterility (Holford et al. 1991; Majewska-Sawka and Sadoch 2003). However, it is currently thought that grouping and migration of cell organelles is vital not only for precise distribution thereof into daughter cells, but rearrangements of cell organelles ensure an efficient course of cell division. For instance, in meiosis with simultaneous cytokinesis, in which the cell wall is formed only at the end of the process, i.e. during telophase II, there are two rounds of chromosome separation within one cell and cell organelle groups as equatorial plates, spatially limiting karyokinesis sites. It is postulated that the presence of an equatorial organelle plate prevents fusion of separating chromosomes or emerging karyokinetic spindles (Kudlicka and Rodkiewicz 1990; Rodkiewicz et al. 1992; Bednara et al. 1986, 1995; Tchórzewska et al. 1996, 2008; Brownfield et al. 2015). Additionally, the course of meiosis also depends on formation of the successive configurations of the microtubular cytoskeleton and plastids play a crucial role in this process, which has been described in numerous analyses of the meiosis process in monoplastid plant species (Brown and Lemmon 1982a, 1985, 1987a, b, 1988a, 1990, 1991a, 2004). Moreover, the phenomenon of cell polarity, which is extremely important for cell and tissue differentiation, depends on various external and internal factors (Noher de Halac and Harte 1985). In terms of the internal factors, irrespective of tissue interactions and additional metabolic factors during meiosis, cell polarity is influenced by formation of vacuoles, migration of the nucleus, dispersion of starch, formation of callose, and, particularly relevant, distribution of organelles (Ekici and Dane 2004). It should also be mentioned that the significant role of cell organelles is not limited to meiocytes, as it has been reported that plastids, which are located in the different cell layers of the microsporangium, serve various very important functions contributing to formation of the functional male gametophyte (Nepi et al. 1996; Clement and Pacini 2001). Thus, it can be pointed out that plastids and mitochondria, apart from their canonical indispensable role in energy metabolism, were adopted to perform additional equally important functions facilitating cell division and differentiation.

This paper, for the first time in almost 100 years, provides a comprehensive overview of information on the chondriokinesis process exclusively during microsporogenesis in plant species. The first survey along with classification developed in 1938 was based on single studies performed at the end of the nineteenth and the beginning of the twentieth centuries. Those investigations were conducted with limited methods and research tools, which substantially reduced the insight into the chondriokinesis process. The significant technological progress achieved later not only allowed validation of the previous observations, but also, what is more important substantially expanded our knowledge about meiotic division in plant cells. Thus, it provides the first complete review on chondriokinesis in microsporogenesis, taking into account numerous plant species. Although the study is focused on 
microsporogenesis, given the abundant literature on the sporogenesis, in the manuscript I took into account chondriokinesis process in monoplastid species, described as a new type of chondriokinesis, which has never been classified before. Additionally, this report provides a current view on the function and mechanism of chondriokinesis, thereby significantly extending the knowledge of this very important process in male gametophyte formation.

\section{Types of chondriokinesis}

\section{Chondriokinesis in early prophase meiocytes}

As described for various plants, the sexual life cycle, i.e. the transformation of a diploid sporophyte generation into a haploid gametophyte, is a result of meiotic division, consisting of karyokinesis and cytokinesis as well as the no less important process of chondriokinesis. In the male generative line, meiotic division occurs in pollen mother cells (PMC). Rearrangement of cell organelles, sometimes extremely dynamic, takes place in PMC as early as during early prophase I. The process was observed at the beginning of the twentieth century and described as "cytoplasmic granularities" grouping during prophase I (Marquette 1907; Jungers 1934; Lenoir 1934); however, mitochondria were not distinguished from plastids at that time, hence the descriptions were not precise. Currently, meiosis with both successive and simultaneous cytokinesis is characterised by the presence of various arrangements of plastids and mitochondria in prophase cells. There can be one or two groups of plastids and mitochondria (Albertsten and Palmer 1979; Bednara et al. 1986; Rodkiewicz and Duda 1988; Rodkiewicz et al. 1988a, b; Giełwanowska et al. 2003); a group of plastids and some mitochondria, with other mitochondria surrounding the cell nucleus (Rodkiewicz et al. 1988b, c, d; Brown and Lemmon 2001a); a separate group of plastids and a separate group of mitochondria (Geneves 1967, 1971; Audran 1964); and one group of plastids and mitochondria and another group of numerous endoplasmic reticulum cisternae located on the opposite side of the nucleus (Bednara and Rodkiewicz 1988). These organelle groupings are transient; as described below, they disperse in the cytoplasm and migrate, usually at the end of prophase I, in a way characteristic for each chondriokinesis type.

\section{Equatorial chondriokinesis}

Equatorial chondriokinesis is one of the four main types of the process (Fig. 1). Although plastids and mitochondria in this type are dispersed in the cytoplasm during prophase I (Fig. 1a), during metaphase I they group in the equatorial plane on both sides of the metaphase chromosome plate (Fig. 1b). Such an arrangement of organelles in the metaphase meiocyte classifies chondriokinesis to the equatorial type. Next, during anaphase I, the chondrion gradually disperses in the cytoplasm (Fig. 1c) and forms an equatorial plate between the daughter nuclei during telophase I (Fig. 1d). Cell organelles remain in this position during the second meiotic division (Fig. 1e) until telophase II and, after karyokinesis, they form other plate separating successive daughter nuclei (Fig. 1f). Within such an equatorial arrangement, the cell wall is formed at the end of telophase II (Fig. 1g). Equatorial chondriokinesis was described by Bạkowski (1938) only in meiosis occurring in animal sperm cells. The researcher claimed that this type of chondriokinesis did not take place in the world of plants. Subsequent investigations revealed that equatorial chondriokinesis was characteristic for many plant species. It was described in Tradescantia virginica (Rodkiewicz et al. 1984b, 1986), Clarkia elegans and Lysimachia thyrsiflora (Rodkiewicz et al. 1986), Impatiens sultani and Lonicera japonica (Brown and Lemmon 1988b), and Cypripedium californicum (Brown and Lemmon 1996, 1998). Furthermore, at the end of the twentieth century, numerous analyses focused on the distribution of plastids and mitochondria in plant cells provided a detailed description of the organisation of the chondrion in early prophase meiocytes. Cytological analyses of meiosis in Equisetum hyemale (Bednara and Giełwanowska (1987); Bednara and Rodkiewicz 1985; Bednara et al. 1986, 1995; Rodkiewicz et al. 1986, 1992), E. fluviatile (Lehmann et al. 1984; Bednara et al. 1986), E. palustre (Bednara and Giełwanowska (1987); Bednara et al. 1986), E. variegatum (Bednara et al. 1986), Onoclea sensibilis (Marengo 1977; Rodkiewicz and Duda 1988), Stangeria eriopus (Rodkiewicz et al. 1986, 1988a, 1992; Rodkiewicz and Duda 1988), and Impatiens balsamina (Dupuis 1978; Rodkiewicz et al. 1984b, 1986, 1988a, 1992) showed that plastids and mitochondria of these species formed two groups visible at the two cell poles during late prophase I (Fig. 1a1). Such groupings are visible transiently during prophase I, and the organelles disperse in the cytoplasm at the end of this phase (Fig. 1a2). In the successive stages, the organelle rearrangements correspond to equatorial chondriokinesis; therefore, although this process in Equisetum, Onoclea, Stangria, and Impatiens initially has a polar character, it can be regarded as equatorial chondriokinesis as the organelles are grouped in the equatorial plane during metaphase I.

\section{Neutral chondriokinesis equatorial during telophase}

The most frequently described type is neutral chondriokinesis equatorial during telophase, which occurs in the meiosis stage with simultaneous cytokinesis (Fig. 2a-g1). 


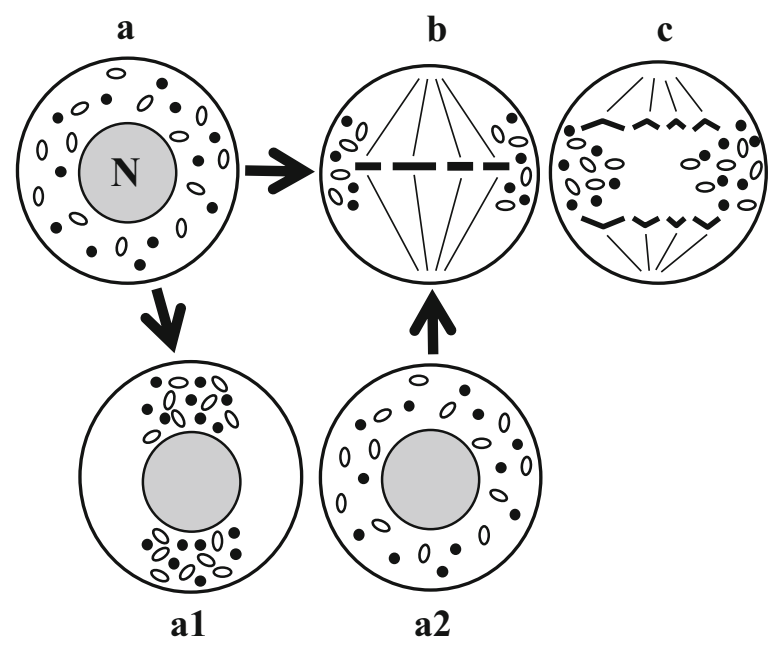

Fig. 1 Equatorial chondriokinesis. $a$ prophase I; $a 1-a 2$ late prophase I in Equisetum, Onoclea, Stangria, and Impatiens; $b$ metaphase I; $c$ anaphase I; $d$ telophase I; $e$ metaphase II; $f$ early telophase II; $g$ late

In this complex chondriokinesis, cell organelles are uniformly distributed in the cytoplasm not only in prophase (Fig. 2a) but also in metaphase (Fig. 2b) meiocytes. They persist in this arrangement until anaphase I, during which they gradually move towards the equatorial plane of the cell (Fig. 2c). During telophase I, an organelle equatorial plate is formed between the daughter nuclei (Fig. 2d1) and the second meiotic division takes place within the meiocyte cytoplasm delineated by the plate composed of plastids and mitochondria (Fig. 2e1). Next, during anaphase II, the chondrion moves between the four forming daughter cells to separate them during telophase II (Fig. 2f1). At the end of telophase II, simultaneous cytokinesis takes place and the cell wall is formed within the organelle plates (Fig. 2g1). This type of chondriokinesis was described by Suessenguth (1921) in Chamaedorea Karwinskiana and Sugiur (1928) in Tropaeolum peregrinum. It was also included in the classification proposed by Bạkowski (1938). Neutral chondriokinesis equatorial during telophase was identified in the investigations of Ribes rubrum (Geneves 1967, 1971), Podocarpus macrophylla (Vasil and Aldrich 1970), Paeonia tenuifolia and Campanula rapanculoides (Dietrich 1973), Pteridium aquilinum (Sheffield and Bell 1979), Dryopteris borreri (Sheffield and Bell 1979; Sheffield et al. 1983), Lycopersicon peruvianum (Pacini and Juniper 1984), Datura inoxa, Nicotiana tabacum and Antirrhinum majus (Dupuis et al. 1988), Solanum nigrum (Bhandari and Sharma 1988), Polystichum loncitis (Bednara and Rodkiewicz 1988), "Sabine Queen" orchid (Brown and Lemmon 1991b), Lilium longiflorum (Dickinson and Heslop-Harrison 1970; Tanaka 1991), Ophioglossum petiolatum (Brown and Lemmon 2001a, b), Psilotum nudum (Lee 1982; Gabarayeva 1985;

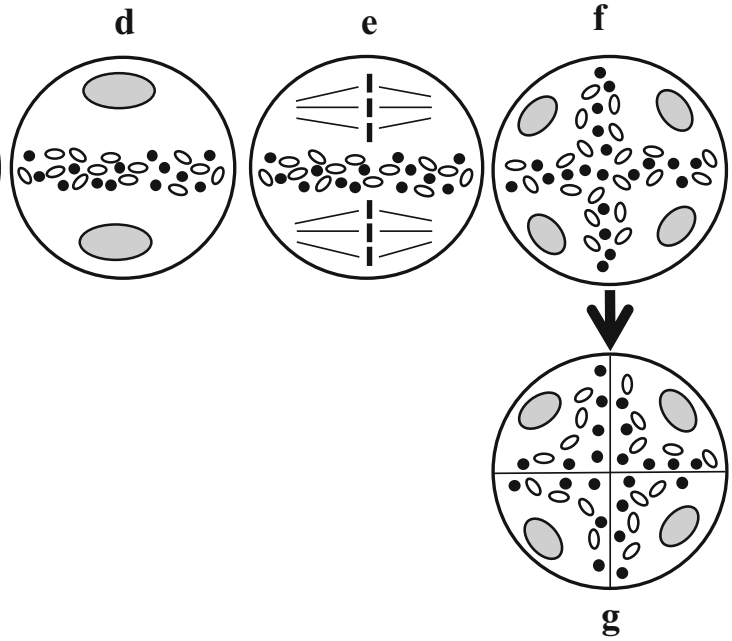

telophase II (Rodkiewicz and Duda 1988, amended). Black spots mitochondria; white spots plastids; $N$ nucleus

Tchórzewska et al. 1996; Tchórzewska and Bednara 2011), Ginkgo biloba (Wolniak 1976; Wang et al. 1988; Brown and Lemmon 2005), Taranna gracilipes (Vinckier and Smets 2007), Armoracia rusticana (Winiarczyk et al. 2007), and Arabidopsis thaliana (Brownfield et al. 2015).

Neutral chondriokinesis equatorial during telophase was also observed during meiosis with successive cytokinesis (Fig. 2a-g2) in such species as Larix europea (Rodkiewicz et al. 1984b; Bednara and Rodkiewicz 1988), "Vista Rainbow" orchid (Brown and Lemmon 1991b), and Tinantia erecta (own unpublished observations). The cell organelles in these plants behave during the first meiotic division in the same way as in the chondriokinesis type described above, i.e. in prophase and metaphase meiocytes, they are uniformly distributed until anaphase I and next they gradually move towards the equatorial plane (Fig. 2ac) and form an equatorial organelle plate between daughter nuclei during telophase I. However, at the end of telophase I, a callose wall is formed in the organelle plate (Fig. 2d2), unlike during meiosis with simultaneous cytokinesis, and the second meiotic division proceeds in the bi-cellular meiocyte (Fig. 2e2). In this case, the cell organelles are still dispersed in the cytoplasm until late anaphase II. Then, they gradually move again towards the equatorial plane between the emerging daughter nuclei and form an organelle plate during telophase II (Fig. 2f2). This is followed by the second stage of successive cytokinesis and a cell wall between the daughter nuclei is formed within the organelle band (Fig. 2g2). In summary, it can be concluded that the cell wall formed after the first meiotic division delineates sites in the cell where karyokinesis takes place. Consequently, the cell organelles can be dispersed and evenly distributed in the meiocyte cytoplasm during the 


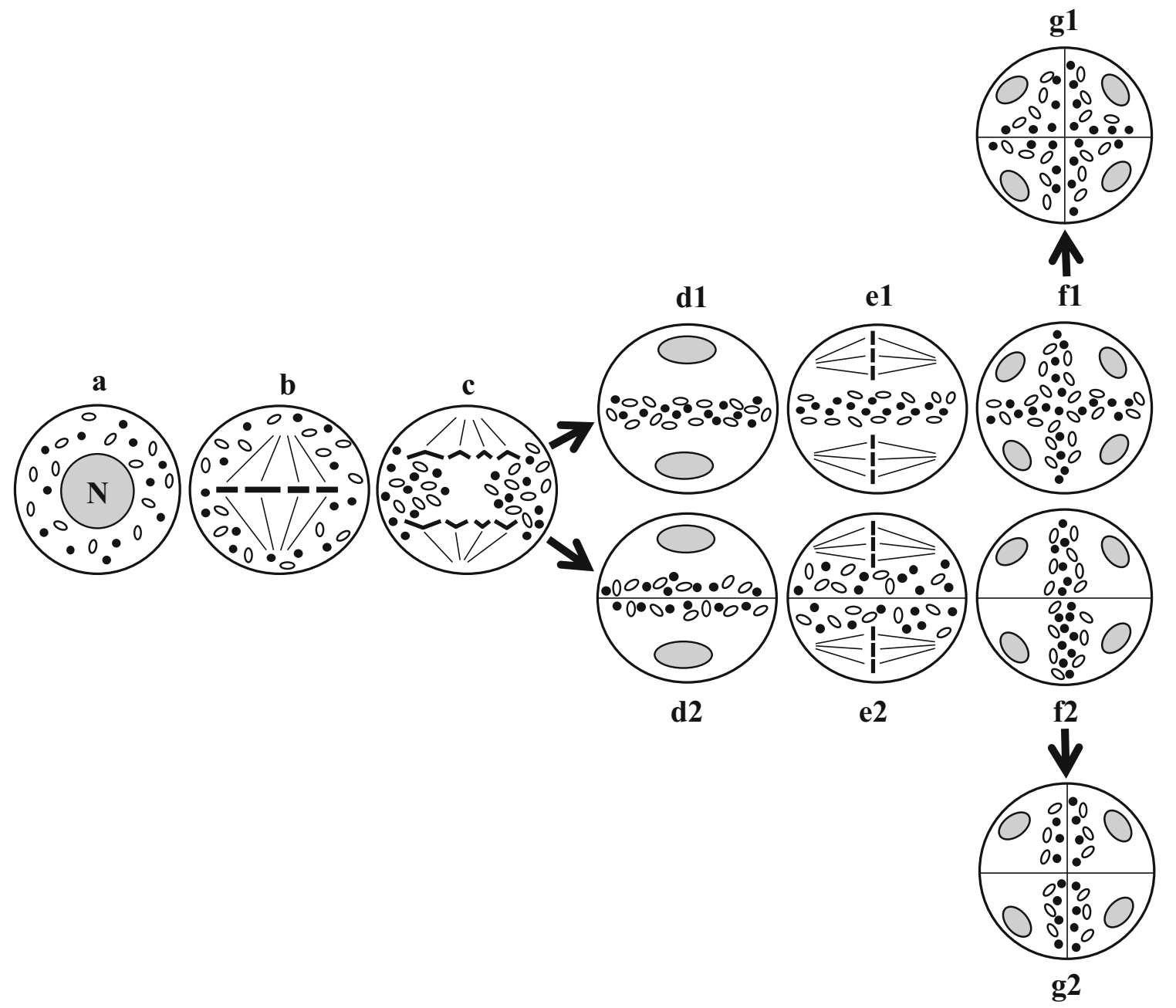

Fig. 2 Neutral chondriokinesis equatorial during telophase: $a-g 1$ microsporogenesis with simultaneous cytokinesis, $a-g 2$ microsporogenesis with successive cytokinesis. $a$ prophase I; $b$ metaphase I;

second meiotic division, which is not observed at simultaneous cytokinesis, and there is no wall after the first meiotic division.

\section{Lateral chondriokinesis equatorial during telophase}

Lateral chondriokinesis equatorial during telophase was described by Bakowski in Marsilia quadrifolia based on the single study by Marquette (1908). Initially, cell organelles are dispersed in the cytoplasm in this type of chondriokinesis (Fig. 3a); next, they are grouped on one side of the nucleus in the equatorial plane during late prophase I (Fig. 3b). This arrangement persists during metaphase I, beside the metaphase chromosome plate (Fig. 3c); next, the group moves towards the equatorial plane of the cell during anaphase I (Fig. 3d). During the subsequent meiotic phases (Fig. 3e-h), cell organelles move in a way that is characteristic for equatorial $c$ anaphase I; $d 1, d 2$ telophase I; $e 1, e 2$ metaphase II; $f 1, f 2$ early telophase II; $g 1, g 2$ late telophase II (Bąkowski 1938, amended)

chondriokinesis with simultaneous cytokinesis, i.e. they form an equatorial organelle plate during telophase I and II, which is a barrier delineating cytoplasmic spaces where karyokinesis proceeds. Lateral chondriokinesis equatorial during telophase was later described in Delphinium elatum (Bednara et al. 1995), Nymphaea alba (Rodkiewicz and Duda 1988; Rodkiewicz et al. 1988a, 1989, 1992; Bednara et al. 1995), and Ophioglossum vulgatum (Giełwanowska et al. 2003).

\section{Capsular chondriokinesis}

Another main type is capsular chondriokinesis (Fig. 4), in which cell organelles are uniformly distributed in the cytoplasm at the beginning of prophase I (Fig. 4a), but at the end of this phase they are grouped in the form of a visible layer surrounding the cell nucleus (Fig. 4b). From this moment, karyokinesis in the first and second meiotic 


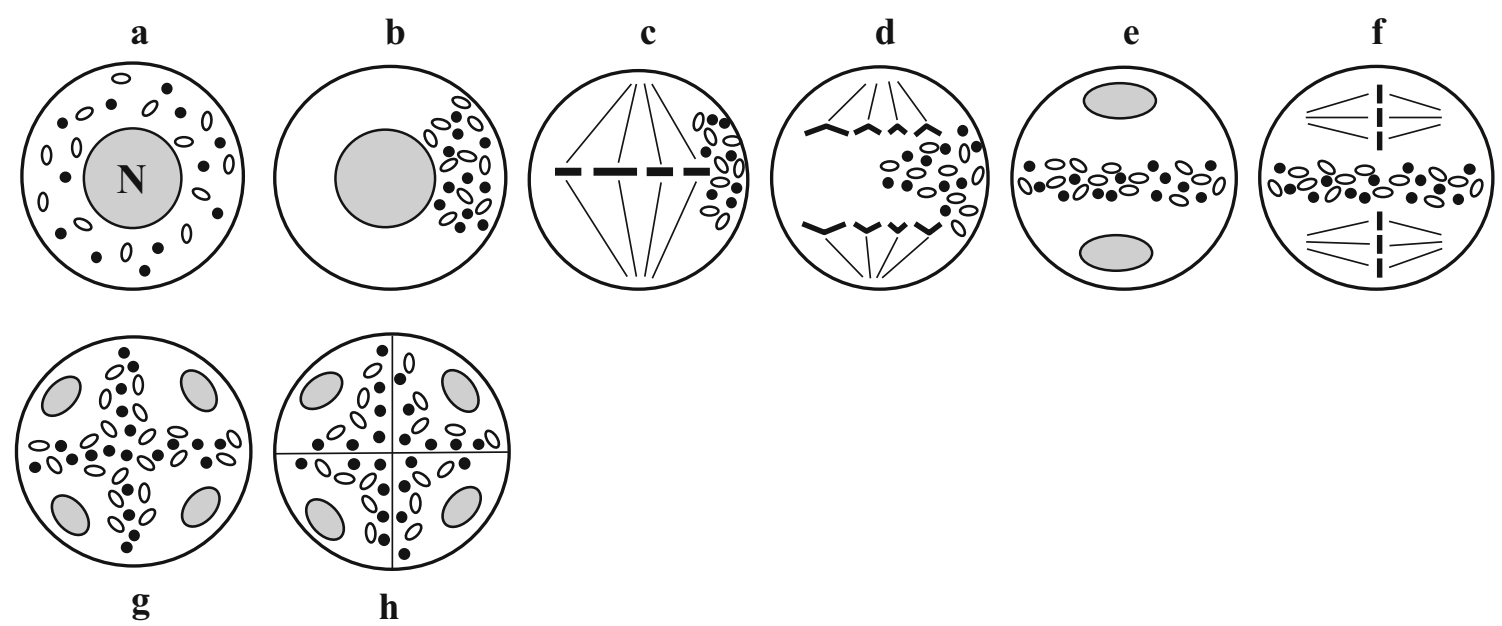

Fig. 3 Lateral chondriokinesis equatorial during telophase. $a$ early prophase I; $b$ late prophase I; $c$ metaphase I; $d$ anaphase I; $e$ telophase I; $f$ metaphase II; $g$ early telophase II; $h$ late telophase II (Rodkiewicz and Duda 1988, amended)
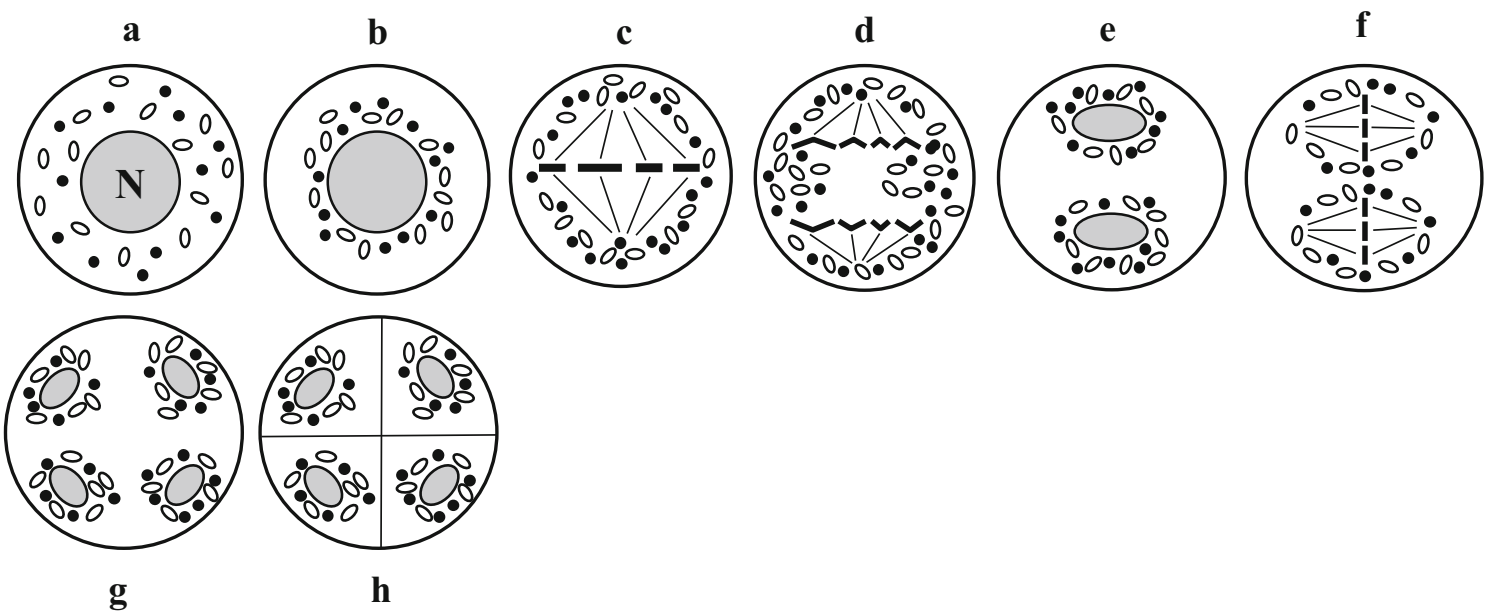

Fig. 4 Capsular chondriokinesis. $a$ early prophase I; $b$ late prophase I; $c$ metaphase I; $d$ anaphase I; $e$ telophase I; $f$ metaphase II; $g$ early telophase II; $h$ late telophase II (Rodkiewicz and Duda 1988, amended)

divisions proceeds in the cytoplasm delineated by a cellorganelle envelope. During metaphase I, organelles form a dense layer surrounding the karyokinetic spindle with metaphase chromosomes (Fig. 4c). During anaphase I, the organelles are temporarily dispersed (Fig. 4d) until formation of two daughter nuclei during telophase I; then they group again around the nuclei and form a dense layer (Fig. 4e). The second meiotic division occurs inside the capsules, which are mainly formed by plastids and mitochondria (Fig. 4f). Next, likewise during anaphase I, the organelles migrate during anaphase II and the cell organelle capsule is formed around the four nuclei emerging during telophase II (Fig. 4g). Simultaneous cytokinesis takes place at the end of telophase II (Fig. 4h).

Capsular chondriokinesis was initially described as perinuclear zones of dense granular cytoplasm; some researchers regarded it as aggregates of fixation artefacts
(Luxenburg 1927). Nĕmec (1930) was the first to describe capsular chondriokinesis in Larix decidua. Next, this chondriokinesis type was described in Lavatera (Byxbee 1900), Larix europea (Devise 1922), Gossypium and Althea (Denham 1924), Thespis (Youngman 1927), and Larix dahurica (Prosina 1928). In the previous classification, Bạkowski (1938) cites only the reports of microsporogenesis observed in Cucumis sativus by Heimlich (1929) and the study performed by Migdalska (1934), who observed capsular chondriokinesis in Gladiolus gandaviensis and G. primulinus. This type of chondriokinesis was not verified in other species in further studies, with the exception of plants from the family Malvaceae (Lavatera, Gossypium and Althea). At present, capsular chondriokinesis is regarded as characteristic for all representatives of the family Malvaceae. To date, it has been described in Malva sylvestris (Rodkiewicz and Duda 1988; Rodkiewicz 
et al. 1988a; Kudlicka and Rodkiewicz 1990), Lavatera trimestris (Kudlicka and Rodkiewicz 1990), Lavatera thuringiaca (Tchórzewska et al. 2008, 2013), and Gossypium arboreum and Alcea rosea (Tchórzewska et al. 2013). Noteworthy is the finding reported recently, which shows that the characteristic grouping of organelles around the cell nucleus persists after the end of meiosis, even after the disintegration of the tetrad into single microspores found in Gossypium arboreum and Lavatera thuringiaca (Tchórzewska et al. 2013).

\section{Capsular chondriokinesis equatorial during telophase}

Capsular chondriokinesis equatorial during telophase represents the complex type of chondriokinesis. In this type of rearrangements, cell organelles are initially dispersed in the cytoplasm of prophase meiocytes (Fig. 5a), and form a capsule around the cell nucleus at the end of prophase I (Fig. 5b). As in the capsular type, the first meiotic division takes place within the space delineated by cell organelles (Fig. 5c). However, unlike in the capsular type, the organelles are dispersed during anaphase I and are grouped during telophase I as an equatorial plate between daughter nuclei (Fig. 5d). From this moment, chondriokinesis proceeds as the equatorial type. Such migrations of cell organelles during microsporogenesis have been observed in Helleborus foetidus (Nicolosi-Roncati 1910), Ginkgo biloba (Mann 1924), Nephrodium molle (Senjaninova 1927), Equisetum palustre (Lewitsky 1926), E. limosum (Jungers 1934), and Hemerocallis fulva fl. pleno (Fullmer 1899; Sienicka 1929), which was included in the classification proposed by Bąkowski (1938). Later, this type of chondriokinesis was confirmed in Helleborus foetidus (Echlin and Godwin 1968) and described in Chondrilla juncea (Kościńska-Pająk and Bednara 2003).

\section{Lateral capsular chondriokinesis equatorial during telophase}

Lateral capsular chondriokinesis equatorial during telophase (Fig. 6a-d) is a variation of capsular chondriokinesis equatorial during telophase (described above), with the organelle capsule surrounding the dividing chromosomes on one side of the nucleus (Fig. 6c). Such grouping was described in Petunia violacea (Matsuda 1928) and Nymphaea alba (Guignard 1898) and included in the classification developed by Bąkowski (1938). However, subsequent investigations did not confirm the lateral capsular chondriokinesis equatorial during telophase in $\mathrm{Nym}$ phaea alba, which exhibited lateral chondriokinesis equatorial during telophase (Rodkiewicz and Duda 1988; Rodkiewicz et al. 1988a, 1989, 1992; Bednara et al. 1995).

\section{Neutral chondriokinesis}

The neutral chondriokinesis type was first described in the meiocytes of Tetraclinis articulata (Saxtona 1913) and Equisetum variegatum (Lenoir 1934), and this was mentioned in the classification by Backowski (1938). The species are characterised by meiosis with successive cytokinesis proceeding during microsporogenesis, i.e. the second meiotic division takes place in the dyad. In this type of chondriokinesis, cell organelles are uniformly dispersed in the meiocyte cytoplasm throughout the meiosis stages (Fig. 7a-f). In recent years, this type has been identified in Allium sativum (Winiarczyk 2009) and A. ampeloprasum (own unpublished observations).

\section{Neutral-polar chondriokinesis}

In neutral-polar chondriokinesis, cell organelles are uniformly distributed in the cytoplasm in all the meiosis stages (Fig. 8a-d). However, their concentration is higher at the cell poles during metaphase I (Fig. 8b) and telophase I (Fig. 8c). This chondriokinesis type was observed in Lupinus albus (Milovidov 1928) and Equisetum limosum (Becker and Siemaszko 1936) and was included in the classification proposed by Bạkowski; however, to date, these data have not been verified and no reports of this type of chondriokinesis in meiosis have been published.

\section{Polar chondriokinesis}

According to the classification developed by Bakowski, polar chondriokinesis is one of the four main types of the process. In this type, cell organelles are dispersed in the cytoplasm during prophase I (Fig. 9a) and accumulated at
Fig. 5 Capsular

chondriokinesis equatorial during telophase. $a$ early prophase I; $b$ late prophase I; $c$ metaphase I; $d$ telophase I (Bąkowski 1938)
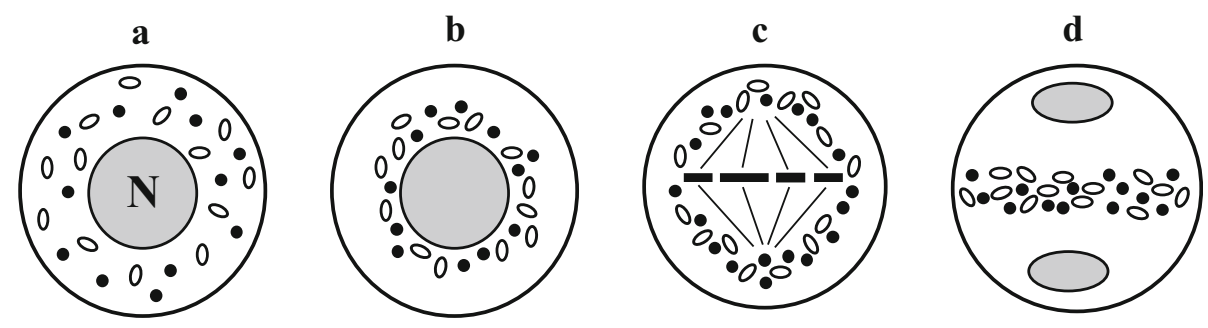
Fig. 6 Lateral capsular chondriokinesis equatorial during telophase. $a$ early prophase I; $b$ late prophase I; $c$ metaphase I; $d$ telophase I; $e$ prophase II (Bąkowski 1938, amended)
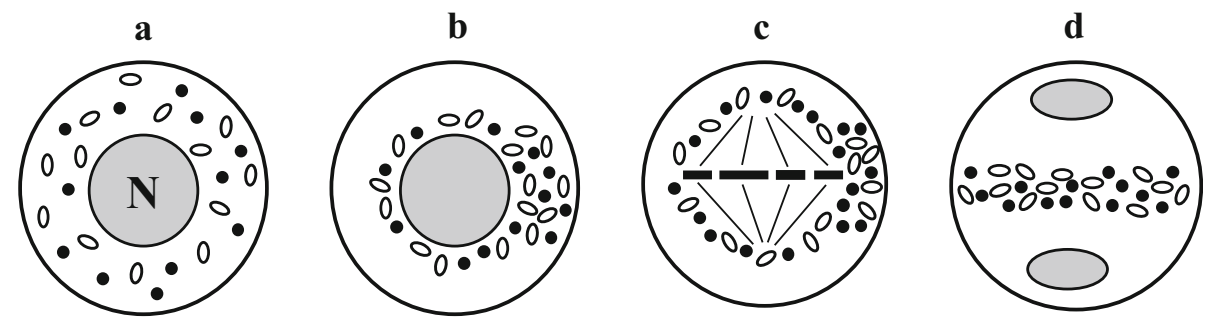
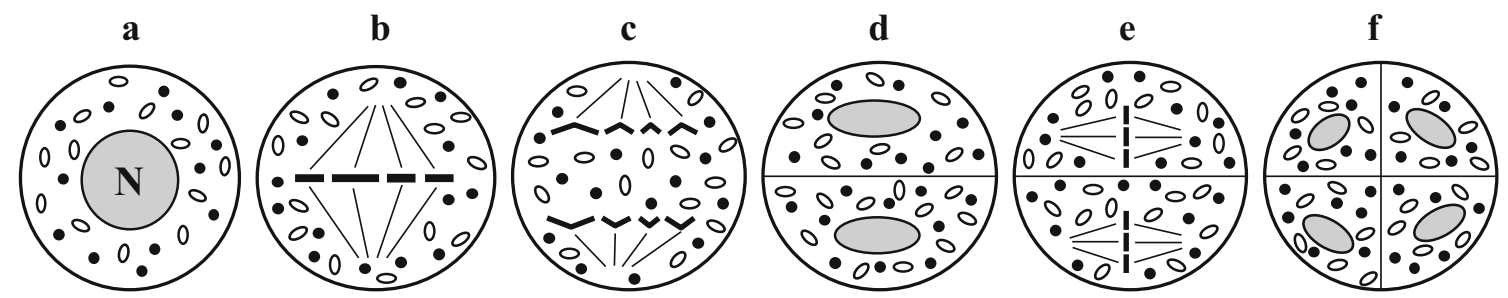

Fig. 7 Neutral chondriokinesis. $a$ prophase I; $b$ metaphase I; $c$ anaphase I; $d$ telophase I; $e$ metaphase II; $f$ telophase II (Bąkowski 1938, amended)

Fig. 8 Neutral-polar chondriokinesis. $a$ prophase I; $b$ metaphase I; $c$ telophase I; $d$ prophase II (Bąkowski 1938)

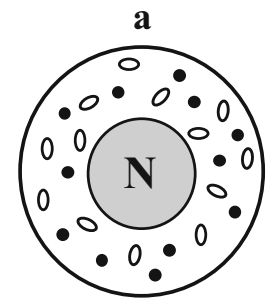

the opposite poles of the cell during metaphase I (Fig. 9b). They persist in these polar clusters until telophase I (Fig. 9c), i.e. until formation of the cell wall and a dyad. Plastids and mitochondria in the bi-cellular meiocyte are uniformly distributed in the cytoplasm (Fig. 9d) and such an arrangement persist until the end of meiosis. This type of chondriokinesis during meiosis was only described by Gugnard (1898) in Limodorum abortivum. It should be emphasised that although Bạkowski classifies polar chondriokinesis as the main type, there have been no other reports of polar chondriokinesis in microsporogenesis.

\section{Capsular-polar chondriokinesis}

Capsular-polar chondriokinesis represents the complex type of the process, in which dispersed cell organelles in
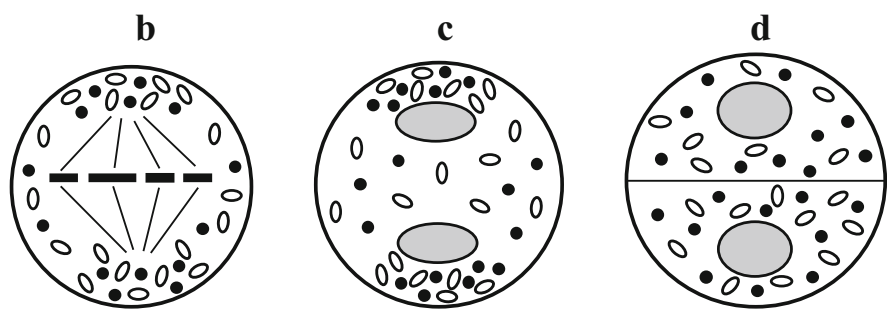

early prophase meiocytes (Fig. 10a) begin to group around the nucleus during late prophase (Fig. 10b). The first meiotic division proceeds within the characteristic capsule formed by the organelles, as in the capsular chondriokinesis type. However, a majority of cell organelles in this arrangement are located at the cell poles (Fig. 10c). Next, during telophase II, all organelles are arranged at the two cell poles, as in polar chondriokinesis (Fig. 10d). After formation of the callose wall between the daughter nuclei during the second meiotic division, cell organelles are uniformly distributed in the cytoplasm (Fig. 10e). Capsular-polar chondriokinesis was classified by Bakowski (1938) based on the work on Magnolia Yulan published by Guignard (1898) and on the findings concerning meiosis in Riccia Frostii described by Black (1913). Later publications did not report this type of chondriokinesis.
Fig. 9 Polar chondriokinesis. $a$ prophase I; $b$ metaphase I; $c$ telophase I; $d$ prophase II (Bąkowski 1938)
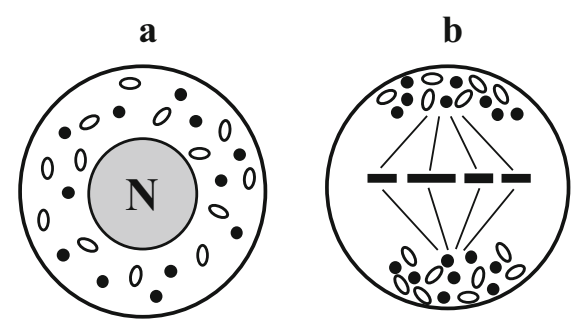

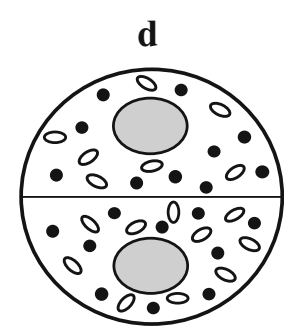




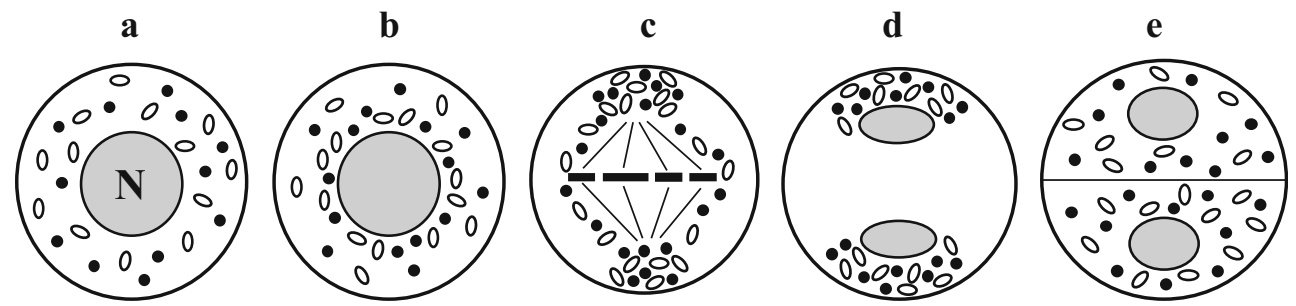

Fig. 10 Capsular-polar chondriokinesis. $a$ early prophase I; $b$ late prophase I; $c$ metaphase I; $d$ telophase I; $e$ prophase II (Bąkowski 1938 , amended)

\section{Monoplastidic chondriokinesis}

Unique plastid polarity during meiosis was observed in hornworts by von Mohl (1839), Nageli (1844), Strasburger (1880), and Davis (1899), but was never considered in Bąkowski's classifications. This process was later studied using electron microscopy and immunofluorescence methods, providing more details of chondriokinesis in monoplastid liverwort, moss, and clubmoss species. In these species, early prophase sporocytes contain a single elongated plastid, a central nucleus, and mitochondria that are unevenly dispersed in the cytoplasm (Fig. 11a). In the later prophase, the nucleus moves towards an acentric position close to the plasma membrane, the plastid divides into two, and the mitochondria are still dispersed in the cytoplasm (Fig. 11b). At the end of prophase I, the two plastids divide again and four plastids are formed that are equidistantly positioned in the sporocyte cytoplasm in a tetrahedral arrangement. The nucleus migrates in this phase and is located centrally in the sporocyte at the end of prophase I (Fig. 11c). In the subsequent phase of meiosis, i.e. metaphase I, plastids are located at the cell poles close to the cytoplasmic membrane; in turn, mitochondria are grouped at the chromosomes in the cell equatorial plane in a manner typical of equatorial chondriokinesis (Fig. 11d). In consecutive meiosis phases, the mitochondria are translocated and grouped as in equatorial chondriokinesis, forming an equatorial plate during telophase I and II, which delineates spaces where karyokinesis takes place (Fig. 11e-g). In turn, plastids in monoplastid species exhibit a completely different arrangement than that of the mitochondria. Initially, they are located near the nuclear envelope (prophase I); in the successive phases of meiosis, they are arranged near the cell poles, often close to the cytoplasmic membrane (Fig. 11b-g). According to the criteria used by Bạkowski (1938), chondriokinesis in monoplastid species resembles the equatorial type due to the specific location of mitochondria in meiosis phases that are critical for classification (metaphase I and telophase I). In contrast, the polar arrangement of four plastids, which are associated with formation of karyokinetic spindles, indicates polar chondriokinesis in respect to rearrangement of plastids. Meiosis in monoplastid species was extensively described by Brown and Lemmon for Rhynchostegium serrulatum (Brown and Lemmon 1982a, b), Amblystegium riparium (Brown and Lemmon 1982c), Atrichum undulatum and Entodon seductrix (Brown and Lemmon 1987a, 1987b), Marattia (Brown and Lemmon 1997),
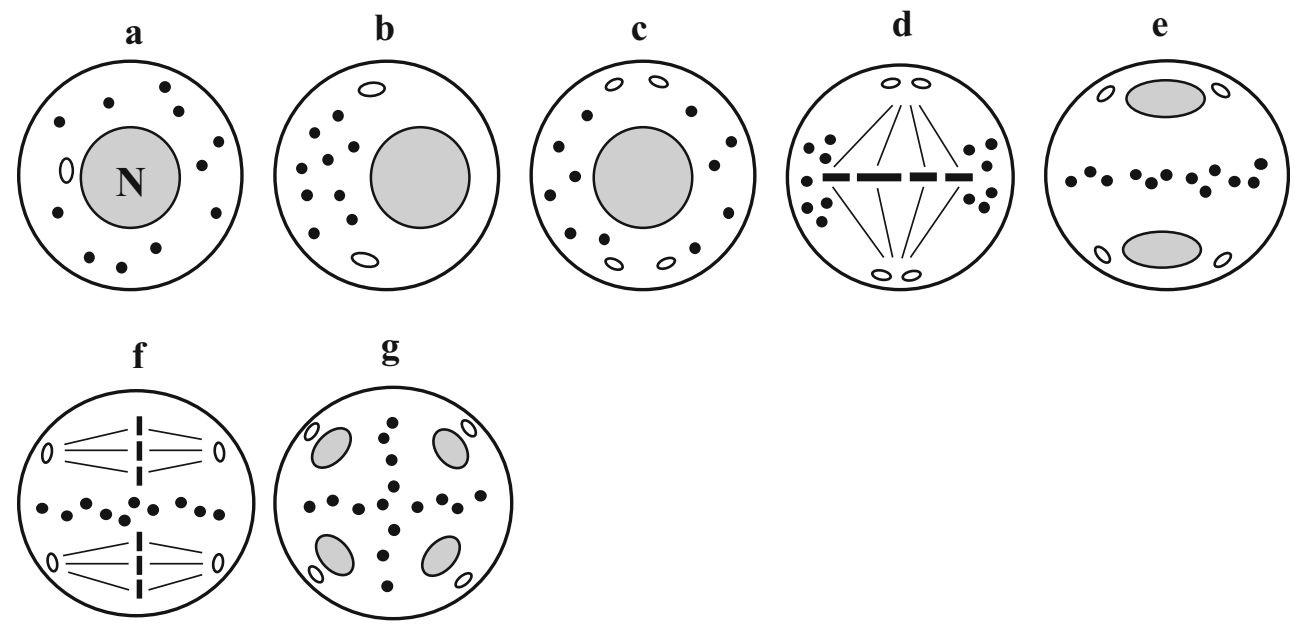

Fig. 11 Monoplastidic chondriokinesis. $a$ prophase I (early); $b$ prophase I (leptoten-zygoten); $c$ prophase I (pachyten-diploten); $d$ metaphase I, $e$ telophase I; $f$ metaphase II; $g$ telophase II (Brown and Lemmon 1988a, amended) 
Angiopteris evecta (Brown and Lemmon 2001a), Phaeoceros laevis and Notothylas breutelii (Brown and Lemmon 1990), Isoetes melanopoda (Brown and Lemmon 1987a, b, 1991a), and Selaginella arenicola (Brown and Lemmon 1985, 1991a).

\section{Role and mechanism of chondriokinesis}

Chondriokinesis during meiosis is a widespread phenomenon in all analysed plant species, even from systematically distant groups (horsetails, mosses, ferns, Gymnosperms, and Angiosperms). The universal occurrence of the process implies its high conservatism and its probable origin at an early stage of plant evolution; however, the course of the process varies between plant species. It should be emphasised, that the role of chondriokinesis has not been synthetically presented as yet, and currently there are many data indicating varied relevance of the process in the meiotic division of the plant cell.

It is thought that the most fundamental role of the specific grouping of organelles throughout the phases of meiosis is to ensure equal distribution of organelles between the tetrad cells (Senjaninova 1927; Geneves 1967; Wolniak 1976; Dupuis 1978; Brown and Lemmon 1982b), which guarantees formation of identical, metabolically active microspores. This is confirmed by the fact that organelles, which are initially dispersed in the meiocyte cytoplasm, are grouped (e.g. neutral chondriokinesis equatorial during telophase) during the key meiosis phases (telophase I and telophase II), which ensures appropriate segregation into daughter cells. With time, when many biological phenomena were better explored at the molecular level, i.e. the importance of cytoplasmic inheritance and the role of semi-autonomous cell organelles in the formation of fertile pollen grains, chondriokinesis was assumed to ensure proper cytoplasmic inheritance of genetic material in the plant cell, wherein both the plastid and the mitochondrial genomes are equally responsible for cytoplasmic inheritance (Sears 1980; Hagemann and Schröder 1989; Kuroiwa 1991; Mogensen 1996; Nagata 2010). The impact of plastid or mitochondrial DNA on offspring traits has been described, especially restriction fragment length polymorphisms (RFLPs) were used to follow the organellar DNA inheritance (Boblenz et al. 1990; Derepas and Dulieu 1992; Hu et al. 1996; Trusty et al. 2007; Hansen et al. 2007; Matsushima et al. 2008b). In many plant species, the presence of plastid or mitochondrial DNA in male reproductive cells determining the potential for cytoplasmic inheritance has been shown (Zhang et al. 2003). Yet, this question seems debatable, as some authors claim that the presence of plastids in sperm cells does not indicate their inclusion in the zygote (Lombardo and Gerola 1968; Reboud and Zeyl 1994). It is, however, indisputable that cytoplasmic male sterility (CMS) is determined by a lack of the mitochondrial genome (Holford et al. 1991; Chase 2006; Wang et al. 2006). Hence, proper segregation of cell organelles is a key process in the formation of a fertile male gametophyte.

Besides the basic function of chondriokinesis (i.e. equal distribution of organelles and involvement in cytoplasmic inheritance), it was proposed that cell organelles constitute a barrier limiting the sites in the meiocyte cytoplasm in which karyokinesis takes place (Kudlicka and Rodkiewicz 1990; Rodkiewicz et al. 1992; Bednara et al. 1986, 1995; Tchórzewska et al. 1996, 2008; Brownfield et al. 2015). Organelles forming a capsule or an equatorial plate prevent fusion of karyokinetic spindles or separating chromosomes during the second meiotic division, serving as a "substitute of the cell plate" (Bednara et al. 1986). This idea was supported by the fact, that cell organelles were dispersed in the meiocyte cytoplasm even if they were grouped as an equatorial plate at the end of telophase I. This phenomenon has been described in many species characterised by meiosis with successive cytokinesis, in which neutral chondriokinesis equatorial during telophase occurs (Rodkiewicz et al. 1984b; Bednara and Rodkiewicz 1988; Brown and Lemmon 1991b). Additionally, in meiosis with successive cytokinesis, during neutral chondriokinesis equatorial during telophase, organelles are arranged in an equatorial plate during telophase II when another cell plate is formed. In this case, another function of chondriokinesis can be inferred, i.e. cell organelles are involved in cell plate formation (Rodkiewicz et al. 1986, 1988a, 1989).

Another function that can be assigned to chondriokinesis is related to the role of cell organelles in determination of meiocyte polarisation. This idea was formulated based on the observation of pollen development in gymnosperms, where plastids in the microspore tetrad remain close to the proximal wall of the tetrad after meiosis. The polarisation is important, as the prothallus cells develop at the proximal wall of pollen cells in gymnosperms and the pollen tube grows from the distal wall (Rodkiewicz et al. 1984a). The relevance of organelle grouping for polarisation of megasporocytes during megasporogenesis is particularly evident. Polarisation of meiocytes is extremely important in the process of female gametophyte development, given the competition between megaspores for formation of a functional megaspore, which will develop into the embryo sac (Steward and Gifford 1967; De Boer-de Jeu 1978; Willemse and Bednara 1979; Willemse and De Boer-de Jeu 1981; Bednara et al. 1981; Ekici and Dane 2004).

An additional function of chondriokinesis is the relationship between plastids and the organisation of tubulin cytoskeleton in the plant cell. This phenomenon has been 
Fig. 12 Graphic summary of all chondriokinesis types identified in sporogenesis or microsporogenesis.

$A$ classification developed by Bąkowski (1938). B unclassified chondriokinesis in monoplastid species

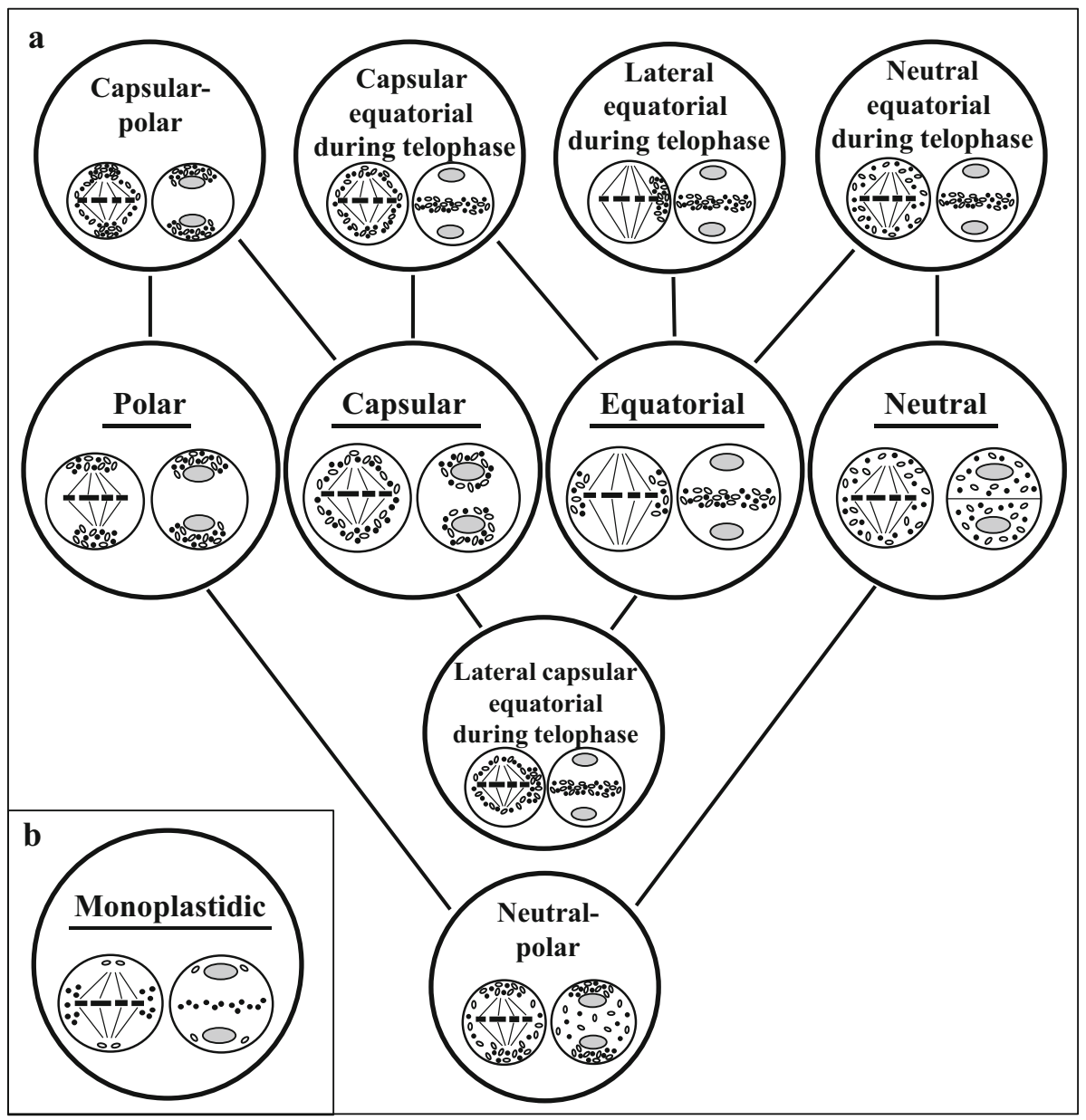

described in numerous reports on meiosis in monoplastid plant species (Brown and Lemmon 1982a, 1985, 1987a, b, 1988a, 1991a, b, 2004, 2006). The acentrosomal spindle formed in plants begins polymerisation with $\gamma$-tubulin, which is the major component of microtubule organizing centres (MTOCs). Observations of meiosis in monoplastid plants revealed that $\gamma$-tubulin was located at the plastid envelope (Shimamura et al. 2004); therefore, the spindle apparatus is organised in association with plastid migration and division (Shimamura et al. 2003). Furthermore, division polarity has been described in Bryophyte meiosis, indicating that the prophase system of axially aligned microtubules determines the site of cytokinesis. Since microtubules are associated with plastids, the location of plastids determines the cell division plane (Brown and Lemmon 1987a).

The molecular mechanism of cell organelle transport and movement during cell division remains obscure. One of the first reports of the mechanism of organelle movement during meiosis suggests that this process is functionally linked to the cytoskeleton (Wolniak 1976). It should be emphasised that the phenomenon of migration of cellular organelles associated with the cytoskeleton has been repeatedly shown in animal cells (Stebbings 1990), lower plant cells (Menzel 1985; Busby and Gunning 1988), and higher plant cells (Tanaka 1991; Brownfield et al. 2015). Involvement of both the tubulin (MT) and actin (MF) cytoskeleton in migration of organelles was reported. Although most reports are primarily focused on somatic cells (Williamson 1993; Ligrone and Duckett 1998; Olyslaegers and Verbelen 1998; Kandasamy and Meagher 1999), it can be assumed that, due to the prevalence of this phenomenon, the mechanism involved in cytoskeleton-assisted organelle movement is universal and can be referred to meiotically dividing generative cells. As shown in $\mathrm{Ni}$ cotiana tabacum protoplast cells, during initial steps of cell division, organelles are surrounded by "actin baskets" and these baskets facilitate their preparatory organisation during cell division; subsequently the "actin baskets" lose their integrity and individual organelles are tethered to acting filaments, which form a dense cytoplasmic network (Kandasamy and Meagher 1999; Sheahan et al. 2004). This leads to enmeshment of organelles and dependence of their location on dynamically changing cytoskeleton configurations (Sheahan et al. 2004). Consequently, organelles embedded at an appropriate place and time within 
Table 1 Chondriokinesis types identified in sporogenesis or microsporogenesis in plant species

\begin{tabular}{|c|c|c|c|}
\hline \multicolumn{2}{|c|}{ Chondriokinesis } & \multirow{2}{*}{ Species } & \multirow{2}{*}{$\begin{array}{l}\text { Author } \\
\text { Marengo (1977); Rodkiewicz and Duda (1988) }\end{array}$} \\
\hline \multirow[t]{13}{*}{ M } & \multirow[t]{13}{*}{ Equatorial } & & \\
\hline & & Impatiens balsamina & Dupuis (1978); Rodkiewicz et al. (1984a, b, 1986, 1988a, 1992) \\
\hline & & Tradescantia virginica & Rodkiewicz et al. (1984a, b, 1986) \\
\hline & & Equisetum variegatum & Bednara et al. (1986) \\
\hline & & Equisetum palustre & Bednara and Giełwanowska (1987), Bednara et al. (1986) \\
\hline & & Equisetum fluviatile & Lehmann et al. (1984); \\
\hline & & & Bednara et al. (1986) \\
\hline & & Equisetum hyemale & $\begin{array}{l}\text { Bednara and Giełwanowska (1987); Bednara and Rodkiewicz (1985); Bednara } \\
\text { et al. (1986, 1995); Rodkiewicz et al. }(1986,1992)\end{array}$ \\
\hline & & Clarkia elegans & Rodkiewicz et al. (1986) \\
\hline & & and Lysimachia thyrsiflora & \\
\hline & & Stangeria eriopus & Rodkiewicz et al. (1986, 1988a, 1992); Rodkiewicz and Duda (1988) \\
\hline & & $\begin{array}{l}\text { Impatiens sultani and } \\
\text { Lonicera japonica }\end{array}$ & Brown and Lemmon (1988b) \\
\hline & & Cypripedium californicum & Brown and Lemmon $(1996,1998)$ \\
\hline \multirow[t]{25}{*}{$\mathrm{C}$} & \multirow{25}{*}{$\begin{array}{l}\text { Neutral equatorial during } \\
\text { telophase }\end{array}$} & Chamaedorea Karwinskiana & Suessenguth (1921) \\
\hline & & Tropaeolum peregrinum & Sugiura (1928) \\
\hline & & Ribes rubrum & Geneves $(1967,1971)$ \\
\hline & & Podocarpus macrophylla & Vasil and Aldrich (1970) \\
\hline & & Paeonia tenuifolia, and & Dietrich (1973) \\
\hline & & Campanula rapanculoides & Sheffield and Bell (1979) \\
\hline & & Pteridium aquilinum & Sheffield and Bell (1979); Sheffield et al. (1983) \\
\hline & & Dryopteris borreri & Pacini and Juniper (1984) \\
\hline & & Lycopersicon peruvianum & Dupuis et al. (1988) \\
\hline & & Datura inoxa & Bednara and Rodkiewicz (1988) \\
\hline & & and Nicotiana tabacum & Bhandari and Sharma (1988) \\
\hline & & and Antirrhinum majus & Brown and Lemmon (1991b) \\
\hline & & Polystichum loncitis & Dickinson and Heslop-Harrison (1970); Tanaka (1991) \\
\hline & & Solanum nigrum & Brown and Lemmon $(2001 \mathrm{a}, \mathrm{b})$ \\
\hline & & Orchids “Sabine Queen” & Lee (1982); Gabarayeva (1985); \\
\hline & & Lilium longiflorum & Tchórzewska et al. $(1996,2011)$ \\
\hline & & Ophioglossum petiolatum & Wolniak (1976); Wang et al. (1988); \\
\hline & & Psilotum nudum & Brown and Lemmon (2005) \\
\hline & & Ginkgo biloba & Vinckier and Smets (2007) \\
\hline & & Taranna gracilipes & Winiarczyk et al. (2007) \\
\hline & & Armoracia rusticana & Brownfield et al. (2015) \\
\hline & & Arabidopsis thaliana & Rodkiewicz et al. (1984a, b); \\
\hline & & Larix europea & Bednara and Rodkiewicz (1988) \\
\hline & & Orchids "Vista Rainbow” & Brown and Lemmon (1991b) \\
\hline & & Tinantia erecta & personal communication \\
\hline \multirow[t]{5}{*}{$\mathrm{C}$} & \multirow{5}{*}{$\begin{array}{l}\text { Lateral equatorial during } \\
\text { telophase }\end{array}$} & Marsilia quadrifolia & Marquette (1908) \\
\hline & & Delphinium elatum & Bednara et al. (1995) \\
\hline & & Nymphaea alba & Rodkiewicz and Duda (1988); Rodkiewicz et al. (1988a, 1989, 1992); Bednara \\
\hline & & Ophioglossum vulgatum & et al. (1995) \\
\hline & & & Giełwanowska et al. 2003 \\
\hline
\end{tabular}

cytoskeleton become considerably less mobile (Tirlapur and Konig 2001), which probably facilitates nearly equal distribution of cell organelles during cell division. Such a mechanism, with the involvement of the actin cytoskeleton, probably manages chondriokinesis in meiotically dividing cells, as indicated in Psilotum nudum. In this species, the 
Table 1 continued

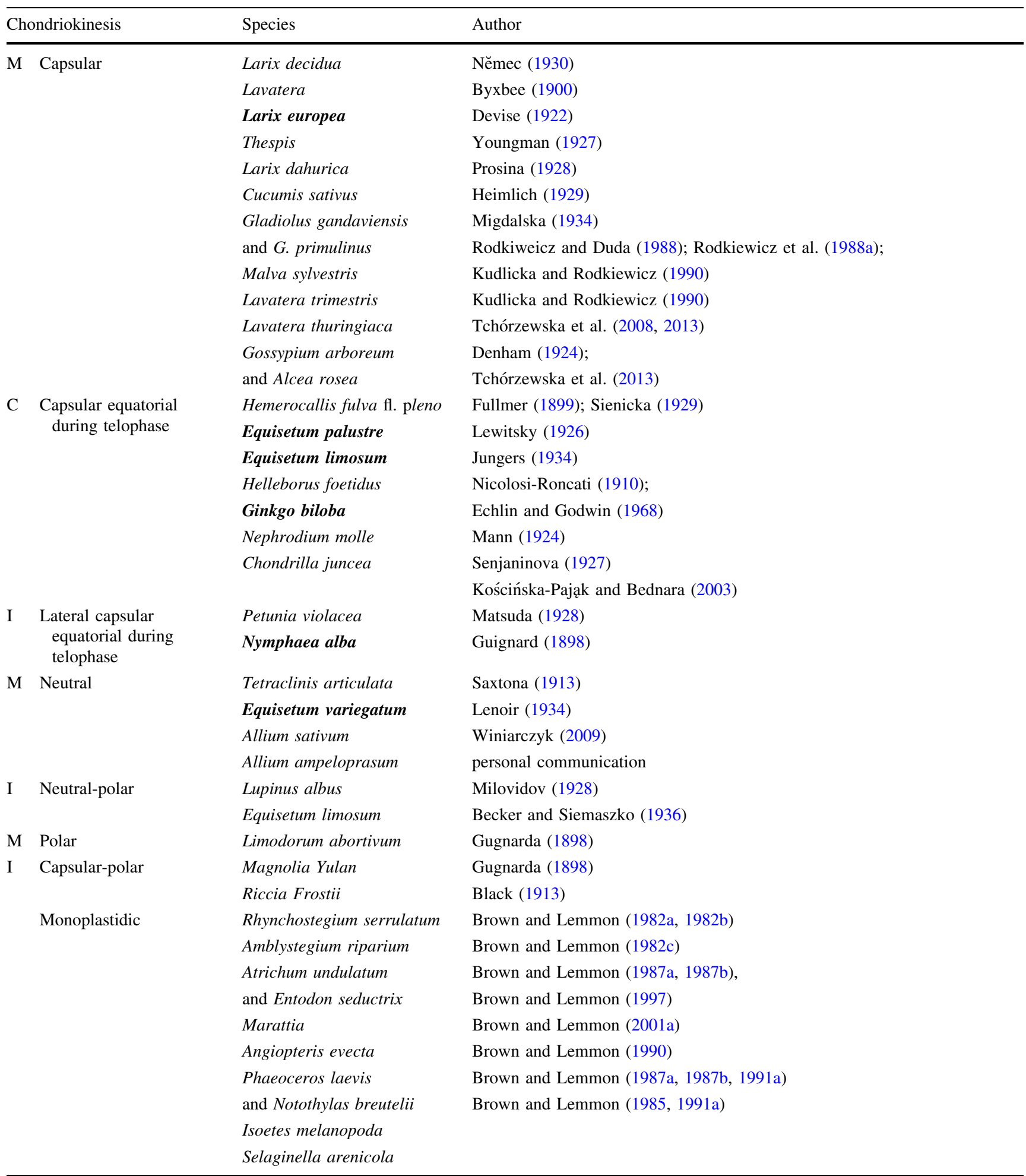

In bold—species with chondriokinesis assigned in recent studies to different types than those suggested by Bąkowski (1938)

$M$ main, $C$ complex, $I$ intermediate chondriokinesis types (acc. to classification proposed by Bąkowski 1938)

destruction of the actin cytoskeleton during the consecutive stages of meiosis induced disturbances in the course of chondriokinesis (Tchórzewska et al. 2011). Some authors claim that organelle repositioning depends on actin filaments, but not on microtubules (Sheahan et al. 2004), however, analyses of the tubulin cytoskeleton in 
combination with capsular chondriokinesis in microsporogenesis in Lavatera thuringiaca showed a close relationship between MT configurations and the position of cell organelles. It seems that the radially oriented MTs around the nucleus in prophase I meiocytes (late leptotene), observed in L. thuringiaca, are associated with organelle assembly around the nucleus, which leads to formation of the species-specific organelle capsule. Later, tangentially oriented MTs in prophase I (diakinesis), which surround organelle clusters around the forming chromosomes, were described in this species. These observations indicate that, by limiting the space in the cell, the characteristic MT configuration maintains cell organelles in a strictly specified space around the forming chromosomes, which probably leads to reduced dynamics of organelle movement and thus allowing their nearly equal distribution. This conclusion is confirmed by investigations showing that the destruction of the tubulin cytoskeleton not only caused disturbances in the course of karyokinesis but also affected the chondriokinesis pattern (Tchórzewska et al. 2008).

In summary, it can be concluded that MTs and MFs play an active role in organelle redistribution within the cell, but depending on the type of cell and the phase of its life cycle, the movement mechanism is based on the tubulin and/or actin cytoskeleton.

\section{Conclusion}

An important process in the complex generative reproduction of plants is the meiotic cell division, which ensures appropriate distribution of genetic material between daughter cells. The success of this process is determined by a number of orchestrated phenomena, with the prominent example of chondriokinesis, ensuring a proper course of karyokinesis and cytokinesis. It can be assumed that in the early evolution of plants, chondriokinesis simply determined efficient "nearly uniform" segregation of cell organelles together with their DNA, as can be proposed by mathematical modelling for simple systems, ensuring proper inheritance thereof, which has a fundamental role in the formation of daughter cells. However, it is thought that during the evolution of plant cells, chondriokinesis has acquired new functions related to support of karyokinesis, polarisation of meiocytes, determination of the division plane, and formation of the tubulin cytoskeleton. A hypothesis can, therefore, be proposed that the new functions of chondriokinesis acquired during plant evolution, which supports meiotic cell division, facilitated rapid and efficient division of generative cells with minimal energy costs. Thus, the emergence of efficient formation of the male gametophyte allowed reproductive success and dynamic plant adaptation to variable environmental conditions. The great number of types of organelle rearrangements taking place during meiotic division implies a high diversity of the process in the evolution, which is characteristic and constant not only within a species but also within large plant groups, e.g. a family (Malvaceae). The molecular mechanism of chondriokinesis has not been fully explored; however, it can be claimed that the cell organelle movement is driven by the tubulin and/or actin cytoskeleton.

This paper provides the first complete classification of chondriokinesis. Importantly, the role of chondriokinesis was comprehensively illustrated, showing its indispensable role in meiosis, as one of the various factors in harmonised cell division. Graphic representation of all the chondriokinesis types described above is provided in Fig. 12. The types of chondriokinesis taking place during meiosis with the names of species and authors are shown in Table 1. The table presents species (marked in bold) that exhibit different types of organelle arrangement than that shown by Bạkowski in his classification (1938), as indicated in later studies. Furthermore, the table shows monoplastid chondriokinesis, which has not been classified so far.

Author contribution statement DT-conceived the study, interpreted the data, wrote the manuscript.

Open Access This article is distributed under the terms of the Creative Commons Attribution 4.0 International License (http://crea tivecommons.org/licenses/by/4.0/), which permits unrestricted use, distribution, and reproduction in any medium, provided you give appropriate credit to the original author(s) and the source, provide a link to the Creative Commons license, and indicate if changes were made.

\section{References}

Albertsten MC, Palmer RG (1979) Comparative light-microscopic and electron-microscopic study of microsporogenesis in male sterile $\left(\mathrm{MS}_{1}\right)$ and male fertile soybeans (Glycine $\max (\mathrm{L}$.$) Merr.$ Am J Bot 66:253-265

Audran J-C (1964) Contribution à l'étude morphologique et cytologique de la formation du grain de pollen chez le Stangeria paradoxa. Comptes Rendus de l'Académie des Science Paris 258:4322-4325

Bąkowski Z (1938) Versuch einer Klassifizierung der Chondriokinese bei Kormophyten. Acta Soc Bot Pol 15:323-369

Bdnara J, Kuraś M, Rodkiewicz B (1981) Ultrastructural changes during megasporogenesis in Epipactis (Orchidaceae). Acta Soc Bot Pol 50:127-130

Becker WA, Siemaszko JA (1936) Uber das Verhalten der Cytoplasma-einschlusse der Equisetum-Sporen wahrend der Zellteilung. Cellule 45:27-42

Bednara J, Giełwanowska I (1987) Plastydy i mitochondria w sporogenezie u Equisetum. Folia Societatis Scientiarum Lublinensis, vol 29, Biol. I, pp 3-9

Bednara, J, Rodkiewicz B (1985) Distribution of plastids and mitochondria during sporogenesis in Equisetum hyemale. In: 
Willemse MTM, van Went JL (eds) Sexual reproduction in seed plants, ferns and mosses. Pudoc, Wageningen, pp 17-19

Bednara J, Rodkiewicz B (1988) Cytoplasmic organelles in microsporocytes of Larix and sporocytes of Polystichum. Annale Sci Univ Reims 23:51-53

Bednara J, Giełwanowska I, Rodkiewicz B (1986) Regular arrangements of mitochondria and plastids during sporogenesis in Equisetum. Protoplasma 130:145-152

Bednara J, Rodkiewicz B, Szczuka E (1995) The cytoskeleton, organelles and rudimentary cytokinesis in the sporogenesis of simultaneous type in Equisetum, Nymphaea and Delphinium. Adv Plant Reprod Biol 9:16

Bhandari NN (1984) The microsporangium. In: Johri BM (ed) The embryology of angiosperms. Springer, Berlin, pp 71-80

Bhandari NN, Sharma M (1988) Distribution of organelles in the meiocytes during microsporogenesis in Solanum nigrum Linn. In: Programme and abstracts of X-th Intern. symp. In Sexual Reproduction In Higher Plants. Siena Univ

Birky CW (1983) The partitioning of cytoplasmic organelles at cell division. Int Rev Cytol Suppl 15:49-89

Birky CW, Skavaril RV (1984) Random partitioning of cytoplasmic organelles at cell division: the effect of organelle and cell volume. J Theor Biol 21:441-447

Black CA (1913) The morphology of Riccia Frostii. Aust Ann Bot 27:511-532

Blackmore S, Crane PR (1998) The evolution of apertures in the spores and pollen grains of embryophytes. In: Owens SJ, Rudall PJ (eds) Reproductive biology in systematics, conservation and economic botany. Royal Botanic Gardens, Kew, pp 159-182

Boblenz K, Nothnagel T, Metzlaff M (1990) Paternal inheritance of plastids in the genus Daucus. Mol Gen Genet 220:489-491

Brown RC, Lemmon BE (1982a) Ultrastructure of meiosis in the moss Rhynchostegium serrulatum I. Prophasic microtubules and spindle dynamics. Protoplasma 110:23-33

Brown RC, Lemmon BE (1982b) Ultrastructural aspects of moss meiosis: cytokinesis and organelle apportionment in Rhynchostegium serrulatum. J Hattori Bot Lab 53:41-50

Brown RC, Lemmon BE (1982c) Ultrastructure of sporogenese in the moss Amblystegium riparium. I meiosis and cytokinesis. Amer J Bot 69:1096-1107

Brown RC, Lemmon BE (1985) A cytoskeletal system predicts division plane in meiosis of Selaginella. Protoplasma 127:101-109

Brown RC, Lemmon BE (1987a) Division polarity, development and configuration of microtubule arrays in bryophyte meiosis. I. Meiotic prophase to metaphase I. Protoplasma 137:84-99

Brown RC, Lemmon BE (1987b) Division polarity, development and configuration of microtubule arrays in bryophyte meiosis. II. Anaphase I to the tetrad. Protoplasma 138:1-10

Brown RC, Lemmon BE (1988a) Sporogenesis in Bryophytes. Adv Bryol 3:159-223

Brown RC, Lemmon BE (1988b) Microtubules associated with simultaneous cytokinesis of coenocytic microsporocytes. Amer J Bot 75(12): 1848-1856

Brown RC, Lemmon BE (1990) The quadripolar microtubule system and meiotic spindle ontogeny in hornworts (Bryophyta: Anthocerotae). Amer J Bot 77(11):1482-1490

Brown RC, Lemmon BE (1991a) Plastid polarity and meiotic spindle development in microsporogenesis of Selaginella. Protoplasma 161:168-180

Brown RC, Lemmon BE (1991b) Pollen development in orchids. 2, The cytokinetic apparatus in simultaneous cytokinesis. Protoplasma 165:155-166

Brown RC, Lemmon BE (1996) Nuclear cytoplasmic domains, microtubules and organelles in microsporocytes in slipper orchid Cypripedium californicum A. Gray dividing by simultaneous cytokinesis. Sex Plant Reprod 9:145-152
Brown RC, Lemmon BE (1997) The quadripolar microtubule system in lower land plants. J Plant Res 110:93-106

Brown RC, Lemmon BE (1998) Division polarity and plasticity of the meiosis I spindle in Cypripedium californicum (Orchidaceae). Protoplasma 203:168-174

Brown RC, Lemmon BE (2001a) Sporogenesis in eusporangiate ferns: I Monoplastidic meiosis in Angiopteris (Marattiales). J Plant Res 114:223-235

Brown RC, Lemmon BE (2001b) Sporogenesis in eusporangiate ferns: II Polyplastidic meiosis in Ophioglossum (Ophioglossales). J Plant Res 114:237-246

Brown RC, Lemmon BE (2004) $\gamma$-Tubulin, microtubule arrays, and quadripolarity during sporogenesis in the hepatic Aneura pinguis (Metzgeriales). J Plant Res 117:371-376

Brown RC, Lemmon BE (2005) $\gamma$-Tubulin and microtubule organization during microsporogenesis in Ginkgo biloba. J Plant Res 118:121-128

Brown RC, Lemmon BE (2006) Polar organizers and girdling bands of microtubules are associated with $\gamma$-tubulin and act in establishment of meiotic quadripolarity in the hepatic Aneura pinguis (Bryophyta). Protoplasma 227:77-85

Brown RC, Lemmon BE (2013) Sporogenesis in bryophytes: patterns and diversity in meiosis. Bot Rev 79:178-280. doi:10.1007/ s12229-012-9115-2

Brown RC, Lemmon BE, Shimamura M (2010) Diversity in meiotic spindle origin and determination of cytokinetic planes in sporogenesis of complex thalloid liverworts (Marchantiopsida). J Plant Res 123:589-605

Brownfield L, Yi J, Jiang H, Minina EA, Twell D, Kohler C (2015) Organelles maintain spindle position in plant meiosis. Nat Commun 6:6492. doi:10.1038/ncomms7492

Busby CH, Gunning BES (1988) Development of the quadripolar meiotic cytoskeleton in spore mother cells of the moss Funaria hydrometrica. J Cell Sci 91:127-137

Byxbee E (1900) The development of the kariokinetic spindle in the pollenmother-cells of Lavatera. Proc Calif Acad Sci ser II Bot 2:63-82

Chase CD (2006) Cytoplasmic male sterility: a window to the world of plant mitochondrial-nuclear interactions. Trends Genet 23(2):81-90

Clement C, Pacini E (2001) Anther plastids in angiosperms. Bot Rev 67(1):55-68

Davis BM (1899) The spore-mother-cell of Anthoceros. Bot Gaz 28:89-108

Davis GL (1966) Systematic embryology of the angiosperms. Wiley, New York

De Boer-de Jeu MJ (1978) Mgasporogenesis. Meded Landbouwhogeschool Wageningen 78:1-127

Denham HJ (1924) The cytology of the cotton plant I: microspore formation in sea istalnd cotton. Ann Bot 38:407-432

Derepas A, Dulieu H (1992) Inheritance of the capacity to transfer plastids by the pollen parent in Petunia hybrid. Hort $\mathrm{J}$ Hered 83:6-10

Devise R (1922) La figure achromatique et la plaque cellulaire dans les microsporocytes du Larix europea. Cellule 32:247-309

Dickinson HG, Heslop-Harrison J (1970) The behavior of plastids during meiosis in the microsporocytes of Lilium longiflorum. Thunb. Cytobios 6:103-108

Dietrich J (1973) Le cloisonnement simultane des cellules-meres poliniques de deux Dicotyledones: Paeonia tenuifolia (Renonculacees) et Campanula rapanculoides (Campanulacees). Comp Rend Acad Sci Paris 276:509-512

Dupuis F (1978) Etude ultrastructurale de la microgametogenese chez 1'Impatiens balsamina L.: de la diade a la tetrade. Bul Soc Bot France 125:19-25

Dupuis F, Sangwan RS, Sangwan-Norreel BS (1988) Microgametogenesis: some ultrastructural aspects during meiosis in certain angiosperms. Ann Sci Univ Reims 23:75 
Echlin P, Godwin H (1968) The ultrastructure and ontogeny of pollen in Helleborus foetidus L. II. Pollen grain development through the callose special wall stage. J Cell Sci 3:175-186

Ekici N, Dane F (2004) Polarity during sporogenesis and gametogenesis in plants. Biol, Bratisl 59:678-696

Fullmer EL (1899) The development of the microsporangia and microspores of Hemerocallis fulva. Bot Gaz 28:8-18

Furness CA, Rudall PJ (1999) Microsporogenesis in monocotyledons. Ann Bot 84:475-499

Gabarayeva NI (1985) The development of spores in Psilotum nudum (Psilotaceae): changes in cytoplasm and organelles of spore mother cells in metaphase and telophase I of meiosis. Bot Zhur 70:441-450

Geneves L (1967) Sur la repartition et les mouvements des organites cytoplasmiques au cours de la meiose staminale et principalement pendant le telophase heterotypique et homeotypique, dans le Ribes rubrum. C R Acad Sci Paris ser D 265:1913-1916

Geneves L (1971) Phenomenes ultrastructuraux au cours de la meiosestaminale chez Ribes rubrum (Grossulariacees). Bull Soc Bot Fr 118:481-524

Giełwanowska I, Szczuka E, Tchórzewska D, Bednara J (2003) Microtubular cytoskeleton and organelles during sporogenesis of homosporous fern Ophioglossum vulgatum. Biol Bratislava 58(4):851-860

Guignard L (1898) Les centres cinetiques chez les vegetaux. Ann Sc Nat Botan 8:177-220

Hagemann R, Schroder MB (1989) The cytological basis of the plastid inheritance in angiosperms. Protoplasma 152:57-64

Hansen AK, Escobar LK, Gilbert LE, Jansen RK (2007) Paternal, maternal, and biparental inheritance of the chloroplast genome in Passiflora (Passifloraceae): implications for phylogenetic studies. Am J Bot 94:42-46

Harrison CJ, Alvey E, Henderson IR (2010) Meiosis in flowering plants and other green organisms. J Exp Bot 6:2863-2875

Heimlich LW (1929) Microsporogenesis in Cucumis sativus. Cellule 39:5-24

Holford P, Croft J, Newbury HJ (1991) Structural studies of microsporogenesis in fertile and male-sterile onions (Allium cepa L.) containing the cms-S cytoplasm. Theor Appl Genet 82:745-755

Hu ZM, Hu SY, Zhang JZ (1996) Paternal inheritance of plastid DNA in genus Pharbitis. Acta Bot Sin 38:253-256

Jungers V (1934) Mitochondries, chromosomes et fuseau dans les sporocytes de 1'Equisetum limosum. Cellule 43:321-340

Kandasamy MK, Meagher RB (1999) Actin-organelle interaction: association with chloroplast in Arabidopsis leaf mesophyll cells. Cell Motil Cytoskeleton 44:110-118

Kapil RN, Bhatnagar AK (1991) Embryological evidence in angiosperm classification and phylogeny. Bot Jahrb Syst 113:309-538

Kościńska-Pająk M, Bednara J (2003) Microtubule patterns and organelles during microsporogenesis in apomictic Chondrilla juncea L. Acta Biol Crac 45(2):175-182

Kudlicka K, Rodkiewicz B (1990) Organelle coatings of meiotic nuclei during microsporogenesis in Malvaceae. Phytomorphology 40(1-2):33-41

Kuroiwa T (1991) The replication, differentiation, and inheritance of plastids with emphasis on the concept of organelle nuclei. Int Rev Cytol 128:1-62

Lee KW (1982) Ultrastructural study of sporogenesis in Psilotum. Bot Soc Amer Misc Publ 162:17-18

Lehmann H, Neidhart KM, Schlenkermann G (1984) Ultrastructural investigations on sporogenesis in Equisetum fluviatile. Protoplasma 123:38-47
Lenoir M (1934) Étude vitale de la sporogénèse et des phénomènes d'apparence électro-magn étiques concomitants chez l'Equisetum variegatum. La Cellule 42:355-408

Lewitsky G (1926) Die chondriosomen in der Gonogenese bei Equisetum palustre L. Planta 1:301-316

Ligrone R, Duckett JG (1998) The leafy stems of Sphagnum (Bryophyta) contain highly differentiated polarized cells with axial arrays of endoplasmic microtubules. New Phytol 140:567-579

Lombardo G, Gerola FM (1968) Cytoplasmic inheritance and ultrastructure of the male generative cell of higher plants. Planta $82: 105-110$

Luxenburg A (1927) Recharches cytologiques sur les grains de pollen chez les Malvacees. Bull Int Acad Pol Sci Lett B 4(5):363-394

Majewska-Sawka A, Sadoch Z (2003) Cytoplazmatyczna męska sterylność roślin mechanizmy biologiczne $i$ molekularne. Kosmos. Problemy Nauk Biologicznych 52(4):413-423

Mann MC (1924) Microsporogenesis of Ginkgo biloba L. with especial reference to the distribution of the plastids and to cell wall formation. Univ of Calif Publ in Agric Sc 2(8):243-248

Marengo NP (1977) Ultrastructural features of the dividing meiocyte of Onoclea sensibilis. Amer J Bot 64:600-601

Marquette W (1907) Manifestations of polarity in plant cells which apparently are without centrosomes. Beih Bot Centralbl Abt I 21:281-303

Marquette W (1908) Concerning the organization of the spore mother-cells of Marsilia quadrifolia. Trans Wisconsin Acad Sci Arts Let 16:81-106

Matsuda H (1928) On the origin of big pollen grains with an abnormal number of chromosomes. Cellule 38:213-242

Matsushima R, Hu Y, Koyoda T, Sodmergen Sakamoto W (2008) The model plant Medicago truncatula exhibits biparental plastid inheritance. Plant Cell Physiol 49:81-91

Menzel D (1985) Fine structure study on the association of the caulerpalean plastid with microtubule bundles in the siphonalean green alga Chlorodesmis fastigiata Ducker (Udoteaceae). Protoplasma 125:103-110

Michaelis P (1955) Cytologia 20:315

Migdalska B (1934) Developpement du pollen et les nombres des chromosomes chez quelques varieties des Gladiolus. Acta Soc Bot Polon 11:463-484

Milovidov PF (1928) Sur les methodes de double coloration du chondriome et de grains d'amidon. Arch. d'Ant Microsc 24:9-18

Mogensen HL (1996) The hows and whys of cytoplasmic inheritance in seed plants. Am J Bot 83:383-404

Mohl $\mathrm{H}$ von (1839) Ueber die Entwicklung der Sporen von Anthoceros laevis. Linnaea 13: $273-290+1$ plate. (Reprinted 1845. In: Vermischte Schriften Botanischen)

Murty YS (1964) Cytokinesis and microspore tetrad. In: Nair PKK (ed) Advances in palynology. Lucknow, National Botanic Gardens, pp 176-202

Nagata N (2010) Mechanisms for independent cytoplasmic inheritance of mitochondria and plastids in angiosperms. J Plant Res 123:193-199

Nageli C (1844) Zellkerne, Zellenbildung, und Zellenwachstum bei den Pflanzen. Zeitschrift fur Wissenschaftliche Botanik $1: 34-118$

Nĕmec B (1930) Nauka o buñce. Anatomie rostlin-Rostlinopis sv II, Praha Aventinum

Nepi M, Ciampolini F, Pacini E (1996) Plastid differentiation during Cucurbita pepo (Cucurbitaceae) pollen grain development. Sex Plant Reprod 9:17-24

Nicolosi-Roncati F (1910) Formazioni mitocondriali negli elementi sessuali maschili dell'Helleborus foetidus L. Rend Acad Sci Fis e Mat 3a 16(49):109-119 
Noher de Halac I, Harte C (1985) Cell differentiation during megasporogenesis and megagametogenesis. Phytomorhology $35: 189-200$

Olyslaegers G, Verbelen JP (1998) Improved staining of F-actin and co-localization of mitochondria in plant cels. J Mcroscopy 192:73-77

Pacini E, Juniper B (1984) The ultrastructure of pollen grain development in Lycopersicon peruvianum. Caryologia 37:21-50

Prosina MN (1928) Verhalten der Chondriosomen bei der Pollenentwicklung von Larix dahurica Turcz Ztschr Zellforsch u Mikr Anat 7:114-134

Reboud X, Zey C (1994) Organelle inheritance in plants. Heredity $72: 132-140$

Rodkiewicz B, Duda E (1988) Aggregations of organelles in meiotic cells of higher plants. Acta Soc Bot Pol 57(4):637-654

Rodkiewicz B, Bednara J, Kuraś M (1984a) Przejawy biegunowości w komórkach mejotycznych i pomejotycznych. III Ogólnopolska Konferencja „Mechanizmy regulacji morfogenezy układów roślinnych”. Rogów pp. 65-86

Rodkiewicz B, Kudlicka K, Stobiecka H (1984b) Patterns of amyloplast distribution during microsporogenesis in Tradescantia, Impatiens and Larix. Acta Soc Bot Pol 53(4):437-441

Rodkiewicz B, Bednara J, Mostowska A, Duda E, Stobiecka H (1986) The change in disposition of plastids and mitochondria during microsporogenesis and sporogenesis in some higher plants. Acta Bot Neerl 35(5):209-215

Rodkiewicz B, Duda E, Kudlicka K (1988a) Organelle aggregations during microsporogenesis in Stangeria, Nymphaea and Malva. In: Cresti M, Pacini E, Gori P (eds) Sexual reproduction of higher plants. Springer, Wien, pp 175-180

Rodkiewicz B, Duda E, Bednara J (1988b) Organelle agregations during microsporogenesis in Nymphae. Flora 183:397-404

Rodkiewicz B, Bednara J, Duda E, Mostowska A (1988c) Cytoplasmic organelles during meiosis I in microsporocytes of Stangeria. Ann Sci Univ Reims 23:48-50

Rodkiewicz B, Bednara J, Kuraś M, Mostowska A (1988d) Organelles and cell walls of microsporocytes in a cycad Stangeria during meiosis I. Phytomorphology 38:99-110

Rodkiewicz B, Duda E, Bednara J (1989) Organelle aggregations during microsporogenesis in Nymphaea. Flora 183:397-404

Rodkiewicz B, Bednara J, Szczuka E (1992) The organelle aggregation, plastid division and incipient cytokinesis in simultaneous sporo- and microsporogenesis. Ukr Bot Zhurn 49(4):75-80

Saxtona WT (1913) Contributions to the life-history of Tetraclinis articulata Masters, with some notes on the phylogenyof the Cupressoideae and Callitroideae. Ann Bot 27:577-605

Sears BB (1980) Elimination of plastids during spermatogenesis and fertilization in the plant kingdom. Plasmid 4:233-255

Senjaninova M (1927) Chondriokinese bei Nephrodium molle. Zeitschrift Zellforsch Mikr Anat 6:493-508

Sheahan MB, Rose RJ, McCurdy DW (2004) Organelle inheritance in plant cell division: the actin cytoskeleton is required for unbiased inheritance of chloroplasts, mitochondria and endoplasmic reticulum in dividing protoplasts. Plant J 37(3):379-390. doi:10.1046/j.1365-313X.2003.01967.x

Sheffield E, Bell PR (1979) Ultrastructural aspects of sporogenesis in a fern Pteridium aquilinum (L) Kuhn. Ann Bot 44:392-405

Sheffield E, Bell PR (1987) Current studies of the Pteridophyte life cycle. Bot Rev 53:242-290

Sheffield E, Laird S, Bell PR (1983) Ultrastructural aspects of sporogenesis in the apogamous fern Dryopteris borreri. J Cell Sci 63:125-134

Shimamura M, Deguchi H, Mineyuki Y (2003) A review of the occurrence of monoplastidic meiosis in liverworts. J Hattori Bot Lab 94:179-186
Shimamura M, Brown RB, Lemmon BE, Akashi T, Mizuno K, Nishihara N, Tomizawa K-I, Yoshimoto K, Deguchi H, Hosoya H, Horio T, Mineyuki Y (2004) $\gamma$-Tubulin in basal land plants: characterization, localization, and implication in the evolution of acentriolar microtubule organizing centers. Plant Cell 16:45-59

Sienicka A (1929) O budowie kwiatów i procesach tworzenia się pyłku u Hemerocallis fulva L. fl. pleno. Acta Soc Bot Pol VI:296-334

Stebbings H (1990) How is microtubule-based organelle translocation regulated? J Cell Sci 95:5-7

Steward KD, Gifford EM Jr (1967) Ultrastructure of the developing megaspore mother cell of Ginkgo biloba. Amer $\mathrm{J}$ Bot $54: 375-383$

Strasburger E (1880) Zellbildung und Zelllteilung. Jena. Gustav Fisher, pp 364-365

Suessenguth K (1921) Bemerkungen zur meiotischen und somatischen Kernteilung bei einigen Monokotylen. Flora 114:313-328

Sugiura T (1928) Cytological studies on Tropaeolum. II Tropaeolum peregrinum. Bot Mag Tokio 42:553-556

Tanaka I (1991) Microtubule-determined plastid distribution during microsporogenesis in Lilium longiflorum. J Cell Sci 99:21-31

Tchórzewska D, Bednara J (2011) The dynamics of the actin cytoskeleton during sporogenesis in Psilotum nudum L. Protoplasma 248:289-298

Tchórzewska D, Brukhin VB, Bednara J (1996) Plastids and mitochondria comportment in dividing meiocytes of Psilotum nudum. Acta Soc Bot Pol 65(1-2):91-96

Tchórzewska D, Winiarczyk K, Pietrusiewicz J, Bednara J (2008) A new type of microtubular cytoskeleton in microsporogenesis of Lavatera thuringiaca L. Protoplasma 232:223-231

Tchórzewska D, Pietrusiewicz J, Winiarczyk K (2013) Organelle aggregations during microsporogenesis with simultaneous cytokinesis in species from the family Malvaceae (Gossypium arboreum, Alcea rosea, Lavatera thuringiaca). Ann UMCS Lublin-Polonia Sectio C LXVIII 2:35-44. doi:10.2478/v10067012-0032-x

Tirlapur UK, Konig K (2001) Femtosecond near-infrared lasers as a novel tool for non-invasive real-time high-resolution time-lapse imaging of chloroplast division in living bundle sheath cells of Arabidopsis. Planta 214:1-10

Trusty JL, Johnson KJ, Lockaby BG, Goertzen LR (2007) Bi-parental cytoplasmic DNA inheritance in Wisteria (Fabaceae): evidence from a natural experiment. Plant Cell Physiol 48:662-665

Vasil IK, Aldrich HC (1970) A histochemical and ultrastructural study of the ontogeny and differentiation of pollen in Podocarpus macrophyllus D. Don. Protoplasma 71:1-37

Vinckier S, Smets E (2007) A histological study of microsporogenesis in Taranna gracilipes (Rubiaceae). Grana 44:30-44

Wang FH, Li Y, Shao W (1988) Some observations on the ultrastructure of male gametophyte in Ginkgo biloba. Ann Sci Univ Reims 23:45-47

Wang Z, Zou Y, Li X, Zhang Q, Chen L, Wu H, Su D, Chen Y, Guo J, Luo D, Long Y, Zhong Y, Liu Y-G (2006) Cytoplasmic male sterility of rice with Boro II cytoplasm is caused by a cytotoxic peptide and is restored by two related PPR motif genes via distinct modes of mRNA silencing. Plant Cell 18:676-687

Wijnker E, Schnitter A (2013) Control of the meiotic cell division program in plants. Plant Reprod 26:143-158

Willemse MTM, Bednara J (1979) Polarity during megasporogenesis in Gasteria verrucosa. Phytomorphology 29:156-165

Willemse MTM, De Boer-de Jeu MJ (1981) Megasporogenesis and early megagametogenesis. Acta Soc Bot Pol 50:111-120

Williamson RE (1993) Organele movement. Annu Rev Plant Physiol Plant Mol Biol 44:181-202 
Winiarczyk K (2009) Badania embriologiczne bezpłodnych ekotypów Allium sativum L. Habilitation thesis. UMCS publishing, Lublin, Poland, pp 113 (ISSN 1895-7048)

Winiarczyk K, Tchórzewska D, Bednara J (2007) Development of the male gametophyte of an infertile plant Armoracia rusticana Gaertn. Plant Breeding 126:433-439

Wolniak SM (1976) Organelle distribution and apportionment during meiosis in the microsporocyte of Ginkgo biloba. Acta Soc Bot Pol 63:251-258
Youngman W (1927) Studies in the cytology of the Hibisceae. Ann Bot 41:755-777

Zhang Q, Liu Y, Sodmergen (2003) Examination of the cytoplasmic DNA in male reproductive cells to determine the potential for cytoplasmic inheritance in 295 angiosperm species. Plant Cell Physiol 44:941-951 